\title{
Economic analysis of farming and wild collection of seaweeds in Ramanathapuram District, Tamil Nadu
}

\author{
B. JOHNSON, R. NARAYANAKUMAR, A. K. ABDUL NAZAR, P. KALADHARAN \\ AND G. GOPAKUMAR \\ ICAR-Central Marine Fisheries Research Institute, Kochi - 682 018, Kerala, India \\ e-mail: jsfaith@gmail.com
}

\begin{abstract}
The commercially important red alga Kappaphycus alvarezii is widely cultivated along Tamil Nadu coast. Apart from farming, wild collection of seaweed is also being practiced by fishers for their livelihoods. The present study on economics and constraints of farming and wild collection of seaweeds was undertaken in the Ramanathapuram District of Tamil Nadu, employing an expost-facto research design. The study found that the total cost of production for fabricating one bamboo raft (12 x 12 feet) was ₹1,050/-. The crop duration was 45 days and four to six crops were harvested in a year. The average yield was 200-260 kg per raft per crop. The price of harvested kappaphycus on wet and dry weight basis were ₹4 and ₹37.50 per $\mathrm{kg}$ respectively. Majority of seaweed farmers earned around ₹50,000/- to 1,00,000/- annually and the profit margin was $60 \%$. The average gross revenue per trip per group of five members for wild collection of seaweed worked out to ₹6,700/and the capital productivity was 0.30 . It is interesting to note that about $20 \%$ of the respondents were those who left fishing and switched to farming and wild collection of seaweeds.
\end{abstract}

Keywords: Collection, Constraints, Economics, Farming, Kappaphycus alvarezii, Seaweed

\section{Introduction}

Kappaphycus alvarezii yields carrageenan, a commercially important polysaccharide. Carrageenans are used in various commercial applications in the food, pharmaceutical, cosmetics and mining industry (Hayashi and Chow, 2007). The cultivation of $K$. alvarezii was initiated in Philippines during 1960s (Doty and Alvarez, 1975). In India, cultivation of $K$. alvarezii was initiated at Mandapam during 1995-1997 (Eswaran et al., 2002). The cultivation was popularised by PepsiCo during 2002 and later PepsiCo was taken over by AquAgri Processing Pvt. Ltd. in 2008 (Krishnan and Narayanakumar, 2010). Many SHG's of women engaged in seaweed cultivation and collection, were formed by the corporate houses such as PepsiCo and AquAgri (Narayanakumar and Krishnan, 2011).

The results from demonstration and field level adoption of $K$. alvarezii farming revealed that it provides additional income for the coastal fishers (Sakthivel, 1999; Abhiram, 2006; Bindu and Achary, 2006; Reeta, 2006; Sahoo, 2006; Subba Rao et al., 2008; Bindu, 2009). At present, out of the 13 coastal districts in Tamil Nadu, K. alvarezii farming is being adopted in Ramanathapuram, Pudukottai, Thanjavur, Thoothukudi and Kanyakumari districts. Apart from farming, around 5,000 fishers in the Gulf of Mannar and Palk Bay region are involved in wild collection of seaweeds (Gelidiella acerosa, Gracilaria spp., Sargassum spp. and Turbinaria spp.) for their livelihoods, and among the seaweed collectors majority are women.

The review of earlier studies indicated that seaweed farming has proved to be an economically viable alternate livelihood option. It is also hoped that promoting seaweed farming will also help to reduce the fishing pressure since there can be a substantial diversion of manpower from fishing to (seaweed) farming. With this background, an attempt has been made in the present paper to discuss the economics and constraints of farming and wild collection of seaweeds in the southern coast of Tamil Nadu.

\section{Materials and methods}

The study with an expost-facto research design was undertaken in Ramanathapuram District of Tamil Nadu coast where farming and wild collection of seaweed is adopted in large scale. Moreover, seaweed farming was adopted for the first time in this district. Among the 184 villages in Ramanathapuram District, eight villages namely Vedalai, Munaikadu, Mandapam, Pamban, Olaikuda, Sambai, Vadakaddu and Mangadu were selected for the study, since the area and number of rafts used for seaweed farming was more compared to other villages and moreover seaweed collection is done in all 
these villages. A total of 500 sample farmers (which included 100 seaweed collectors) were selected through proportionate random sampling technique (Table 1).

Table 1. Village-wise distribution of seaweed farmers selected for the study

\begin{tabular}{ll}
\hline Name of the village & No of farmers selected \\
\hline Vedalai & 60 \\
Munaikadu & 30 \\
Mandapam & 30 \\
Pamban & 30 \\
Olaikuda & 50 \\
Sambai & 110 \\
Vadakaddu & 110 \\
Mangadu & 80 \\
Total & 500 \\
\hline
\end{tabular}

A pre-tested interview schedule was used for data collection. Data was also collected from seaweed procuring and processing units namely AquAgri Processing Pvt. Ltd. (Manamadurai unit), Linn Plantae Pvt. Ltd. (Ramanathapuram unit) and Shreevas Chemicals, Madurai. Analysis of the economic performance of seaweed farming was assessed by working out the annual fixed cost, operating cost, gross revenue and net operating income through tabular analysis. Operating cost ratio relates variable costs to gross income.

Operating ratio $=$ Total operating costs $/$ Gross returns

Constraints were operationalised as the problems or difficulties encountered by fishers in adoption of seaweed farming practices. The list of constraints encountered by farmers in seaweed farming was ranked using Garrett's ranking technique. It provides the change of orders into numerical scores.

Garrett's formula for conversion of ranks into \% :

Percent position $=100 *\left(R_{i j}-0.5\right) / N_{j}$

where, $R_{i j}=$ Rank given for $i^{\text {th }}$ factor by $j^{\text {th }}$ individual, $N_{j}=$ Number of factors ranked by $j^{\text {th }}$ individual

The percent position of each rank was converted into scores referring to the table (Garrett and Woodworth, 1969). The scores of each respondent were added together against respective factor. It is then divided by the total number of respondents for whom scores were added. In descending order, the mean scores for all the factors were arranged, ranks were given and the most important constraints were identified.

\section{Results and discussion}

\section{Seaweed farming}

Kappaphycus farming is being widely adopted employing floating bamboo raft method in Tamil Nadu coast (Fig 1). In a few places, tube net and monoline culture techniques are also being practiced for seaweed cultivation. The mainframe of floating bamboo raft is of $12^{\prime} \times 12^{\prime}$ '. Four bamboo poles (each of 4' length) are tied diagonally in four corners of mainframe. Nearly 20 polypropylene-twisted ropes along with seed materials are tied in the raft. Around 150-200 g of seaweed fragments are tied at a spacing of $15 \mathrm{~cm}$ along the length of the rope. A total of 20 seaweed fragments can be tied in single rope. The total seed requirement per raft is $60-80 \mathrm{~kg}$. Fish net of $4 \times 4 \mathrm{~m}$ size is tied at the bottom of the raft to avoid grazing. In normal season, a cluster of 10 rafts are positioned in the nearshore area of 1.0 to $1.5 \mathrm{~m}$ depth using a $15 \mathrm{~kg}$ anchor. During rough season, the same cluster has to be installed using two or three anchors.

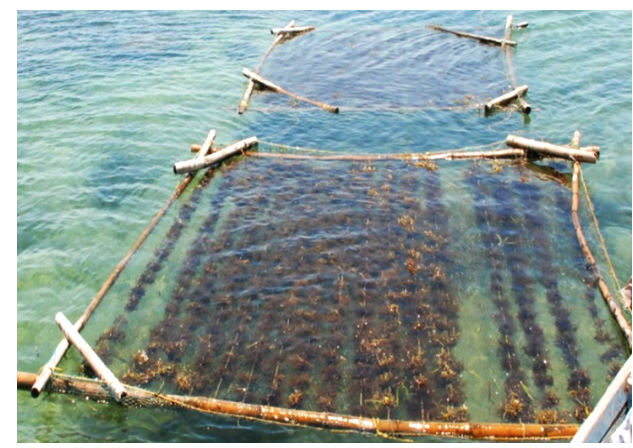

Fig. 1. Floating bamboo raft method of seaweed cultivation

Most of the seaweed farmers used 25 to 45 rafts for their cultivation (Table 2). Due to limitations in space for farming, in majority of the villages a farmer is restricted to use a maximum of only 45 rafts. In Kottaipattinam Village of Pudukottai District, a farmer who used an area of $7 \times 20$ $\mathrm{m}$ for farming, gave it to another person on goodwill agreement for ₹5,000 for seaweed farming. There is a steep decline in the farming of $K$. alvarezii since August 2013 due to "heat stroke" i.e. increase in temperature above $32^{\circ} \mathrm{C}$ in the coastal belt from Vedalai to Verkodu areas where kappaphycus was farmed intensively. Hence there was a reduction in the number of farmers during the year 2014. However, the farming is recovering from the year 2015 .

\section{Economics of seaweed farming}

The total cost of production for making one bamboo raft for $K$. alvarezii farming worked out to be ₹1,050/(Table 3). As the investment is comparatively less and 
Table 2. Distribution of seaweed farmers based on the number of rafts used in each year $(\mathrm{n}=500)$

\begin{tabular}{llllllllllll}
\hline No. of. rafts/year & $\begin{array}{l}2005 \\
(\%)\end{array}$ & $\begin{array}{l}2006 \\
(\%)\end{array}$ & $\begin{array}{l}2007 \\
(\%)\end{array}$ & $\begin{array}{l}2008 \\
(\%)\end{array}$ & $\begin{array}{l}2009 \\
(\%)\end{array}$ & $\begin{array}{l}2010 \\
(\%)\end{array}$ & $\begin{array}{l}2011 \\
(\%)\end{array}$ & $\begin{array}{l}2012 \\
(\%)\end{array}$ & $\begin{array}{l}2013 \\
(\%)\end{array}$ & $\begin{array}{l}2014 \\
(\%)\end{array}$ & $\begin{array}{l}2015 \\
(\%)\end{array}$ \\
\hline Less than 25 & 0 & 0 & 0 & 2 & 42 & 42 & 40 & 30 & 30 & 30 & 30 \\
40 & 0 & 0 & 0 & 2 & 12 & 14 & 16 & 19 & 20 & - & 30 \\
45 & 8 & 10 & 18 & 22 & 44 & 40 & 40 & 45 & 46 & - & 10 \\
50 & 4 & 2 & 4 & 2 & 2 & 2 & 2 & 3 & 4 & - & - \\
More than 90 & 0 & 0 & 0 & 0 & 2 & 2 & 2 & 3 & 2 & - & - \\
\hline
\end{tabular}

Table 3. Cost of making one bamboo raft for seaweed cultivation (2012-2013*; total 6 cycles in a year; with each cycle of 45 days)

\begin{tabular}{|c|c|c|c|c|}
\hline Particulars/Description & $\begin{array}{l}\text { Quantity } \\
\text { required }\end{array}$ & $\begin{array}{l}\text { Cost per raft } \\
(₹)\end{array}$ & Share $(\%)$ & $\begin{array}{l}\text { Economic life } \\
\text { (years) }\end{array}$ \\
\hline $\begin{array}{l}\text { 3-4' dia hallow bamboo poles of 12'x 12' for main } \\
\text { frame + 4'x 4' for diagonals (without any natural } \\
\text { holes and cracks) @ ₹3.75 per ft of bamboo }\end{array}$ & 64 & 240.00 & 29 & 3 \\
\hline $\begin{array}{l}\text { Five-toothed iron anchor of } 15 \mathrm{~kg} \text { each } \\
\text { (@) ₹ } 50 \text { per kg) - one anchor can hold a cluster of } 10 \text { rafts }\end{array}$ & $1.5 \mathrm{~kg}$ & 75.00 & 9 & 10 \\
\hline $\begin{array}{l}3 \text { mm PP twisted rope for plantation - } 20 \text { bits of } 4.5 \mathrm{~m} \\
\text { each (@ ₹ } 130 \text { per kg) }\end{array}$ & $420 \mathrm{~g}$ & 55.00 & 6 & 3 \\
\hline $\begin{array}{l}\text { Cost of HDPE braider pieces } \\
(20 \text { pcs x } 20 \text { ropes }=400 \text { pcs of } 25 \text { cm each) (@ ₹190 per kg) }\end{array}$ & $165 \mathrm{~g}$ & 31.00 & 4 & 3 \\
\hline $\begin{array}{l}\text { Raft framing rope } 6 \mathrm{~m} \times 12 \text { ties per raft } \\
\text { i.e., } 36 \mathrm{~m} \text { of } 6 \mathrm{~mm} \text { rope(@ }(130 \text { per kg) }\end{array}$ & $650 \mathrm{~g}$ & 85.00 & 10 & 3 \\
\hline $\begin{array}{l}\text { Used HDPE fishing net to protect the } \\
\left.\text { raft bottom (4 m x } 4 \text { m size) (@ } 60 \text { ₹ kg } \text { kg }^{-1}\right)\end{array}$ & $1 \mathrm{~kg}$ & 60.00 & 7 & 3 \\
\hline 2 mm rope to tie the HDPE net $(28 \mathrm{~m})$ (@₹130 per kg) & $100 \mathrm{~g}$ & 13.00 & 2 & 3 \\
\hline $\begin{array}{l}\text { Anchoring rope of } 10 \text { mm thickness } \\
\text { (17 m per cluster of } 10 \text { rafts) (@₹ } 130 \text { per kg) }\end{array}$ & $100 \mathrm{~g}$ & 13.00 & 2 & 3 \\
\hline $\begin{array}{l}\text { Raft linking ropes per cluster } 10 \text { rafts, } \\
6 \mathrm{~mm} \text { thick - } 2 \text { ties x } 3 \mathrm{~m} \text { x } 9 \text { pairs = } 54 \text { m length (@₹ } 130 \text { per kg) }\end{array}$ & $100 \mathrm{~g}$ & 13.00 & 2 & 3 \\
\hline Seed material (150 g x 400 ties @ ₹ 3.50 per kg) & $60 \mathrm{~kg}$ & 210.00 & 25 & \\
\hline Raft laying charges & - & 30.00 & 4 & \\
\hline Total initial investment per raft & & 825.00 & 100 & \\
\hline \multicolumn{5}{|l|}{ Fixed costs } \\
\hline Depreciation & & 180.00 & 75 & \\
\hline Interest on investment $(7 \%)$ & & 60.00 & 25 & \\
\hline Total fixed cost (A) & & 240.00 & 100 & \\
\hline \multicolumn{5}{|l|}{ Operating costs } \\
\hline Braider twining charges & & 180.00 & 22 & \\
\hline Transportation & & 150.00 & 19 & \\
\hline Raft maintenance & & 450.00 & 55 & \\
\hline Miscellaneous expenses & & 30.00 & 4 & \\
\hline Total operating costs (B) & & 810.00 & 100 & \\
\hline Total cost of production $(\mathrm{A}+\mathrm{B})$ & & $1,050.00$ & & \\
\hline
\end{tabular}

${ }^{*}$ During the study period, maximum Kappaphycus production was recorded during the year 2012-13. Hence the economics of seaweed cultivation was worked out for 2012-13

farmers were also supported through subsidy scheme, spread of the technology was rapid.

The crop duration is 45 days and in a year, four to six crops per cycle (6 to 9 months) can be harvested depending on the climatic conditions. The $150 \mathrm{~g}$ seed material planted initially, grows upto 500 to $1000 \mathrm{~g}$ in 45 days. From one raft of $12 \times 12 \mathrm{ft}$ size, an average yield of 200-260 kg is obtained (Fig. 2). After retaining $60 \mathrm{~kg}$ as seed material for the next crop, remaining $200 \mathrm{~kg}$ is sold either in fresh or dry weight basis. The average dry weight of the harvested seaweed is $10 \%$. Hence $20 \mathrm{~kg}$ is obtained by drying $200 \mathrm{~kg}$ of fresh seaweed. Farmers receive 


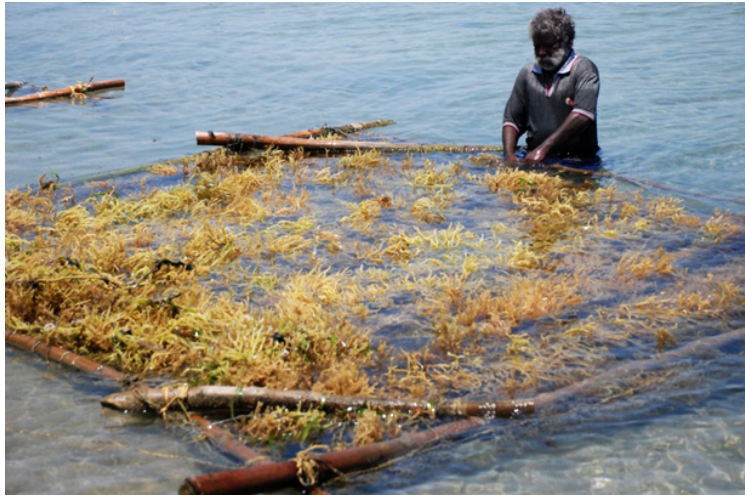

Fig. 2. Seaweed raft ready for harvest

₹4 and ₹37.50 per $\mathrm{kg}$ for fresh and dried seaweed respectively (Fig. 3). Majority of seaweed farmers earn around ₹50,000 to 1,00,000/- annually. The profit margin is $60 \%$ (Table 4 ). About $10 \%$ of the seaweed farmers earn an average annual income of more than one lakh rupees (Fig. 4). This finding indicates that kappaphycus farming provides substantial returns, which in turn helps to improve the livelihood of coastal fisherfolk.

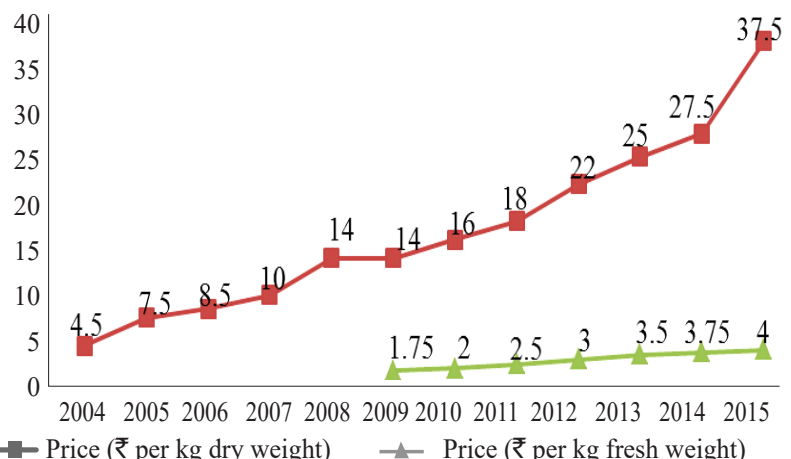

Fig. 3. Price of $K$. alvarezii in Tamil Nadu coast

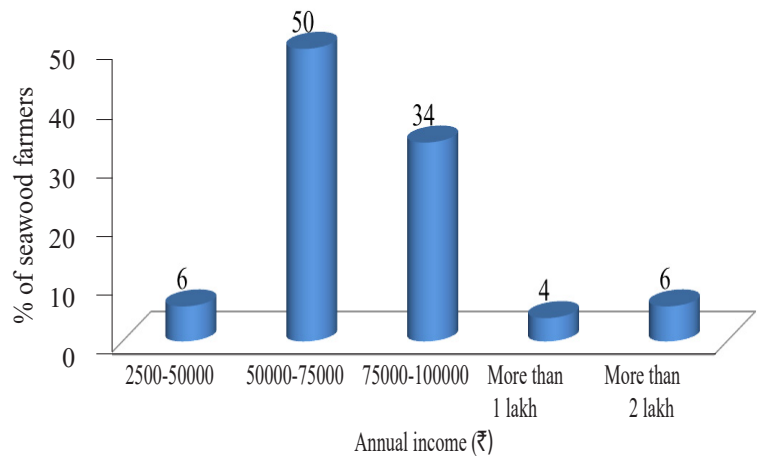

Fig. 4. Distribution of seaweed farmers based on the average annual income in Kappaphycus farming

\section{Marketing of seaweeds}

Most of the seaweed farmers sell their produce at farm site itself, of which $80 \%$ sell their produce in dry
Table 4. Economics of seaweed cultivation from 45 rafts (2012-2013; total 6 cycles in a year; each cycle of 45 days)

\begin{tabular}{ll}
\hline Particulars & $\begin{array}{l}2012-2013 \\
\text { (6 cycles) }\end{array}$ \\
\hline $\begin{array}{l}\text { Annual seaweed production (260 kg per raft) } \\
\text { (Retaining } 60 \mathrm{~kg} \text { for next crop, total seaweed }\end{array}$ & $54,000 \mathrm{~kg}$ \\
production from 45 rafts; 6 cycles) & \\
$\begin{array}{l}\text { Total dried seaweed production } \\
\text { from } 45 \text { rafts; } 6 \text { cycles }\end{array}$ & $5400 \mathrm{~kg}$ \\
Price of dried seaweed (₹per kg) & 22 \\
$\begin{array}{l}\text { Gross revenue (₹) } \\
\text { Total cost of production (₹) } \\
\text { (₹1,050 } \times 45 \text { rafts) }\end{array}$ & $1,18,800$ \\
$\begin{array}{l}\text { Net income (₹) } \\
\text { (Gross revenue - Total cost of production) }\end{array}$ & 47,250 \\
$\begin{array}{l}\text { Profit margin (\%) } \\
\text { Break even price }\end{array}$ & 71,550 \\
\hline
\end{tabular}

form (Table 5). The main marketers were AquAgri Processing Pvt. Ltd., Manamadurai; SNAP Alginate Processing Ltd., Ranipet, Vellore; Linn Plantae Pvt. Ltd., Ramanathapuram; PrasmoAgri, Kumbakonam and Sea6 Energy, Tuticorin. Most of the farmers sell their produce to AquAgri Processing Pvt. Ltd., Manamadurai, since they have buy back arrangements and they even provide subsidy for the farmers to take up farming.

\section{Constraints in K. alvarezii farming}

The constraints encountered by farmers in seaweed farming were ranked using Garrett's ranking technique (Table 6). The prime constraint faced by the farmers was heavy loss of crop due to high temperature/disease. Other constraints were reduction in seaweed yield due to grazing and damage of bamboo rafts during cyclone.

\section{Wild collection of seaweed}

In the year 2015, around 3,700 t of seaweeds (dry weight) were collected from the Tamil Nadu coast. The information on seasonal availability of seaweed is provided in Table 7 . The price offered by the traders to seaweed collectors were: ₹25, ₹80, ₹10 and ₹15 per kg on dry weight basis respectively for Gracillaria spp., Gelidiella spp., Sargassum spp. and Turbinaria spp. (Table 7).

Over the years the price of wild collected seaweeds is increasing and a seaweed collector group (comprising 5 members) earned around ₹6,700 per trip during the year 2015, which was ₹1,200 more in comparison to the year 2012 (Table 8). The average operating cost per trip per group ( 5 members) during the year 2015 worked out to ₹ 2,020/- with gross revenue of ₹6,700/-. The net operating income worked out to ₹4,680/- per trip per group ( 5 members) and the capital productivity was 0.30 
Table 5. Distribution of seaweed farmers according to their marketing behaviour

\begin{tabular}{llll}
\hline \multirow{2}{*}{ Marketing behaviour } & Category & \multicolumn{2}{c}{ Total $(\mathrm{n}=500)$} \\
\cline { 2 - 4 } & & No. & \multicolumn{2}{c}{$\%$} \\
\hline Selling form & Fresh & 100 & 20.00 \\
& Dry & 400 & 80.00 \\
Grading & Clean (Free from other seaweeds and non-decayed seaweeds) & 500 & 100.00 \\
Selling place & Farm site & 500 & 100.00 \\
Selling time & Immediately after harvest & 100 & 20.00 \\
& After drying & 400 & 80.00 \\
Selling terms and conditions & Dried seaweed should be free from moisture and sand & 450 & 90.00
\end{tabular}

Table 6. Constraints faced by farmers in seaweed farming $(n=500)$

\begin{tabular}{lll}
\hline Constraints & Score & Garrett's Rank \\
\hline Heavy loss in seaweed yield due to high temperature/disease & 65.7 & I \\
Reduction in seaweed yield due to grazing & 44.8 & II \\
Damage of bamboo rafts due to cyclone & 32.3 & III \\
Loss due to epiphytism (attachment of undesired seaweeds to the cultured species) & 13.5 & IV \\
\hline
\end{tabular}

Table 7. Price (₹ per kg dry weight) for wild collected seaweeds

\begin{tabular}{|c|c|c|c|c|c|c|}
\hline Species & 2011 & 2012 & 2013 & 2014 & 2015 & Seasonal availability \\
\hline Gracillaria & 10.00 & 15.00 & 18.00 & 20.00 & 25.00 & $\begin{array}{l}\text { September to December \& } \\
\text { February to March }\end{array}$ \\
\hline Gelidiella & 45.00 & 50.00 & 55.00 & 60.00 & 80.00 & February to September \\
\hline Sargassum & 6.00 & 7.00 & 8.00 & 10.00 & 10.00 & September to May \\
\hline Turbinaria & 7.00 & 8.00 & 9.00 & 10.00 & 15.00 & January to July \\
\hline
\end{tabular}

Source: Shreevas Chemicals, Madurai

Table 8. Economics of seaweed collection (₹ per trip per Five persons)

\begin{tabular}{lllll}
\hline Year & 2012 & 2013 & 2014 & 2015 \\
\hline Operating cost (₹) & 1,350 & 1,630 & 1,840 & 2,020 \\
Gross revenue (₹) & 5,500 & 6,150 & 6,600 & 6,700 \\
Net operating income (₹) & 4,150 & 4,520 & 4,760 & 0.28 \\
Operating ratio (Operating cost / Gross revenue) & 0.25 & 0.27 & 0.30 \\
\hline
\end{tabular}

On an average 12 trips were made in a month for seaweed collection. A seaweed collector earns around ₹ 10,000 to 15,000/- per month. Among the wild collected seaweeds, the price of Gelidiella is more compared to Gracillaria, Sargassum and Turbinaria, since gel strength is more for Gelidiella.

Farmers' attitude change towards seaweed farming and collection

It is evident from the economic performance analysis that there is a substantial return/profit from farming as well as wild collection of seaweeds. Hence about $20 \%$ of the respondents were those who left fishing and switched to farming and wild collection of seaweeds, who continue practicing the same in a sustainable manner (Fig. 5). There

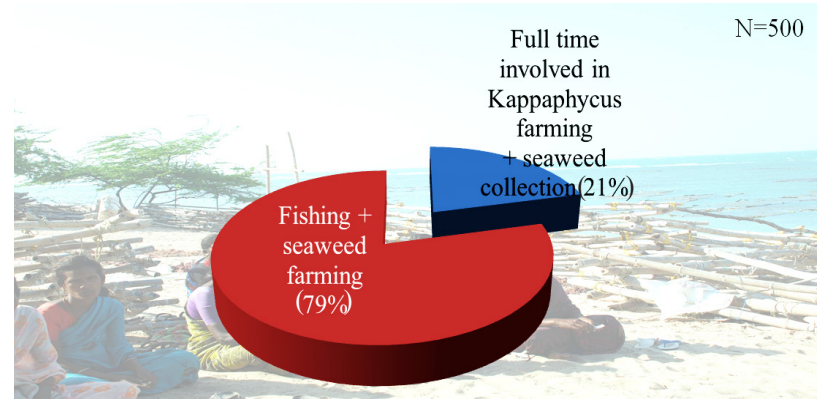

Fig. 5. Distribution of seaweed farmers based on their involvement in farming and wild collection of seaweeds

is a definite shift in the attitude of fishers towards farming and this trend would definitely help in reducing the fishing pressure in near future. 
Analysis of economics and constraints of seaweed farming and collection undertaken in Ramanathapuram District of Tamil Nadu coast revealed that seaweed farming is a simple, low cost technology that provides substantial returns which attracted better adoption among the coastal fisherfolk. Owing to the potential benefits from farming and wild collection of seaweeds, about $20 \%$ of the respondents of the present study were those who left fishing and switched to farming and wild collection of seaweeds. Results of the present study indicated that a fisherman family earns around ₹50,000 to 1,00,000/annually through seaweed cultivation. The profit margin is $60 \%$. This trend clearly shows that any lucrative option like seaweed farming which can supplement capture fisheries is readily accepted and adopted by the marine fisherfolk. Most of the seaweed farmers sell their produce at farm site itself of which $80 \%$ sell their produce in dry form, which is used for carrageenan production. The remaining is sold in fresh form, which is used for liquefied seaweed fertilizer production. The major constraints reported by farmers in seaweed cultivation were heavy loss of crop due to high temperature/disease as well as reduction in seaweed yield due to grazing and damage of bamboo rafts during cyclone.

To overcome the problem of high temperature in the farming of $K$. alvarezii, slightly deeper waters where the temperature is ideal for good growth may be identified for farming. It is essential to bring seaweed cultivation under insurance coverage to compensate the crop loss during natural calamities. Awareness should be created among the seaweed collectors on eco-friendly and hygienic methods of collection

\section{Acknowledgements}

We sincerely thank Dr. A. Gopalakrishnan, Director, ICAR-CMFRI, Kochi for his guidance and support. We also thank the seaweed farmers and collectors and entrepreneurs in the study area for their kind help and co-operation rendered during the study. We express our wholehearted thanks to Mr. Govindaraj and Mr. Senthoor Ganesh for their support in data collection.

\section{References}

Abhiram, S. 2006. Kappaphycus cultivation along Tamil Nadu coast. In: Sahoo Dinabandhu (Ed.), Book of Abstracts, International conference on applied phycology, algae in biotechnology and environment,14-15 February 2006, University of Delhi, New Delhi, p. 9-10.

Bindu, M. S. 2009. Empowerment of coastal communities in cultivation and processing of Kappaphycus alvareziia case study at Vizhinjam Village, Kerala, India. In: Sahoo Dinabandhu (Ed.), Book of Abstracts, $7^{\text {th }}$ Asia-Pacific conference on algal biotechnology, Algal biotechnology in the Asia-Pacific region: New challenges for $21^{\text {st }}$ century, 1 - 4 December 2009, University of Delhi, New Delhi, p. 21. http://www.ugcfrp.ac.in/images/userfiles/Springer\%20paper $\% 202$.pdf

Bindu, M. S. and Achary Kumaraswamy, G. P. 2006. Experimental field cultivation of Kappaphycus alvarezii (Doty) Doty at Vizhinjam Bay, south-west coast of Kerala. In: Sahoo Dinabandhu (Ed.), Book of Abstracts, International conference on applied phycology, algae in biotechnology and environment, 14-15 February 2006, University of Delhi, New Delhi, 58 pp.

Doty, M. S. and Alvarez, V. B. 1975. Status, problem, advances and economics of Eucheuma farms. J. Mar. Tech. Soc., 9: 30-35.

Eswaran, K., Ghosh, P. K. and Mairh, O. P. 2002. Experimental field cultivation of Kappaphycus alvarezii (Doty) Doty ex. P. Silva at Mandapam region. Seaweed Res. Util., 24: 67-72.

Garret, H. E. and Woodworth, R. S. 1969. Statistics in psychology and education. Vakils, Feffer and Simons Pvt. Ltd., Bombay, $329 \mathrm{pp}$.

Hayashi Leila, Paula Edison Jose and Chow Fungyi 2007. Growth rate and carrageenan analyses in four strains of Kappaphycus alvarezii (Rhodophyta, Gigartinales) farmed in the subtropical waters of Sao Paulo State, Brazil. J. Appl. Phycol., 19: 393-399.

Krishnan, M. and Narayana Kumar, R. 2010. Socio-economic dimensions of seaweed farming in India. Special Publication no. 104, Central Marine Fisheries Research Institute, Kochi.

Narayanakumar, R. and Krishnan, M. 2011. Seaweed mariculture: An economically viable alternate livelihood option (ALO) for fishers Indian J. Fish., 58(1): 79-84.

Reeta, J. 2006. Open sea farming of Kappaphycus in India. Training manual, National training workshop on seaweed farming and processing for food, The Thassim Beevi Abdul Kader College for Women, Kilakarai, India, p. 47-53.

Sahoo, D. B. 2006. Creating a million jobs through large-scale seaweed cultivation-a mission towards blue revolution. In: Sahoo Dinabandhu (Ed.), Book of Abstracts, International conference on applied phycology, algae in biotechnology and environment, 14-15 February 2006, University of Delhi, New Delhi, p. 11.

Sakthivel, M. 1999. Resource potential, present status and solutions to the problems of seaweed cultivation in India. Seaweed Res. Util., 21: 15-19.

Subba Rao, P. V., Suresh Kumar, K., Ganesan, K. and Chandra, T. M. 2008. Feasibility of cultivation of Kappaphycus alvarezii (Doty) Doty at different localities on the north-west coast of India. Aquac. Res., 39: 1107-1114.

Date of Receipt $\quad$ : 26.09.2016

Date of Acceptance : 19.10 .2017 